\title{
Effects of Some local Conditions on Leaching Factor of Aridisols in Kalar/Garmian, Kurdistan- Iraq
}

\author{
Salim Neimat Azeez \\ Sulaimani Polytechnic University, Darbandikhan Technical Institute \\ Darbandikhan, Sulaimani, Kurdistan Region, Iraq \\ salim.azeez@spu.edu.iq
}

\begin{abstract}
Five sites were selected in Kalar city on different topographic position. The mean annual rainfall of the study area about $280 \mathrm{~mm}$ with about $24.5 \mathrm{C}^{\circ}$ mean annual temperature. The study area used for rain feed crop production. Morphological properties of the studied pedons indicated that all pedons were developed with Ochric epipedons and Cambic and Argillic endopedons.

The results of particle size distribution show a wide differences between sand and clay in surface horizons except pedon (2) because of low elevation compared with other pedons. Moreover, the results of exchangeable sodium and potassium indicate that pedons (4) and (5) had the lowest value of soil leaching factor which is an indication of the high activity of weathering and leaching processes. In another hand, the results of total element analysis has observed that the silicate ratio were high to indicate the high leaching processes which is the proof of the existence of fine materials movement particularly clay colloids, this is not merely due to the rare rainy weather conditions that are prevalent recently but is a result of wet paleoclimatic conditions, and this movement eventually occurred due to in situ factors. All soils are belonged to Aridisols order with suborders Argids and Cambidsas these soils are in aridic moisture regime include Ochric diagnostic surface horizon with Argillic and Cambic diagnostic subsurface horizons.
\end{abstract}

Keywords: Soil leaching factor, Aridisols, Epipedon, Endopedon.

\section{Introduction}

Kalar city is located in Garmian area and distinguished by low rainfall and high temperature in comparison with other parts of Kurdistan-Iraq. Therefore the vegetation covers naturally poor and the land appears more barren. On the other side, the region is rich in fresh ground water with seasonal and permanent surface water resources particularly in the study areas such as Serwan River which is located beside Kalar city. The lands of the study region are used for economic cultivation especially planting field crops such as wheat and barley, which solely depend on rainfall for irrigation [1]. Studying soil science is very crucial in general and particularly in the current circumstances, as the huge majority of the people are encountering food problems. Precisely, people in Kurdistan region of Iraq are going through difficult economic situations, because the region is solely depending on the oil as an economic source. Despite the existence of multitudinous sources of economy, especially in the field of agriculture where the water supply and the fertile soil are quite suitable for cultivation in most area of the region. It is, thus strongly required to intensify scientific efforts to raise agricultural level, therefore, I have suggested in this research to study the soil leaching factor and its impacts on the soil development, soil maturity and soil classification, and then realizing its degree of fertility through the soil studied families. There are very few studies carried out about Garmian area soils particularly in the last years except some whole studies [2] in spite of the fact that such area are passed through moist climate, we can observe the impact of those conditions. Leaching factor is very important because it is the index for activity of weathering and leaching processes, however, decreasing the value of leaching factor increases the activity of weathering and leaching processes.

The study precisely focuses on the following aims: 1- Studying the effects of in situ factors on leaching factor. 2-Determining the most pedogenic processes in the studied soils.

3- Classifying the studied soils on the bases of family level. 
Kurdistan Journal of Applied Research (KJAR) | Print-ISSN: 2411-7684 - Electronic-ISSN: 2411-7706 | kjar.spu.edu.iq Volume 1 | Issue 2 | December 2016 | DOI: 10.24017/science.2016.1.2.1

\section{Materials and Methods:}

The study area is located in Garmian district, Kurdistan - Iraq. It lies between latitude $34^{\circ} 34^{\prime} 41.0^{\prime \prime}$ to $34^{\circ}$ $37^{\prime} 24.0^{\prime \prime} \mathrm{N}$ and longitude $45^{\circ} 19^{\prime} 10.0^{\prime \prime}$ to $45^{\circ} 21^{\prime} 29.2^{\prime \prime} \mathrm{E}$ with average elevation of $230 \mathrm{~m}$ above sea level. The topographic nature of the study area was obtained from the topographic map of Iraqi Kurdistan region prepared by [3] and from the soil map units of Iraqi soils by [4] and [5] as well. The data of latitudes, longitudes and elevations of soil pedon locations were collected using a (GPS) receiver model GARMIN 72.

The area lies within foot hill physiographic unit [2], in a tectonic side and is located in folds zone [6].The study area climate is within continental semiarid by PE (Potential Evaportranspiration) which described by [7]. According to the [8] the species of native vegetations Cynodon dactylon, Ammi majus, Triflolium resupinatum, Euphorbia Peplus, Lagonychium farctum, Alhagi graeccorum, Lolium rigidum, Hordeum glaucum, Phalaris minor, centaurea iberica, Brassica tournefortii, Silybum marianum, Carthamus oxyacanthus and Avena fatua were present in this area. Soils were classified to the family level using (Keys to Soil Taxonomy) by [9]. Five study sites were selected represent differential topography and natural land use for cultivation in Kalar district in Garmian area to study the leaching factor of these soils and the effect of some soil properties on it. Profiles are dig and described morphologically according to National Survey Handbook [10]. Soil samples were taken from each soil horizon, air dried and mixed to be homogenous, grinded using wood mortar, then passed through $(2 \mathrm{~mm})$ sieve and kept in plastic containers for further analyses. The soil samples were taken from each horizon, to determine some soil properties, including physical properties such as particle size distribution using (International Pipette Method) described by [11]. The silt and clay were separated from sand by washing the dispersed samples through $50 \mu$ sieve, as described by [12]. The diverse silt and clay particles were thus obtained using Pipette Method as cited in [13]. Particle density was measured by Pycnometer Method described by [14], bulk density was determined by Clods Method covering with paraffin wax described by [14] and porosity which obtained from the following equation explained by [15], which indicated in [14].

$$
\begin{gathered}
\% \text { Porosity }= \\
\{1-(\text { Bulk Density } / \text { Partical Density })\} \times 100
\end{gathered}
$$

Chemical properties including organic matter, were estimated Oxidation Method using chromic acid according to (Walkley- Black), depending on [16]. Total calcium carbonate (total lime) was estimated by equilibrium with $(1 \mathrm{~N})$ of hydrochloric acid, as described by [17] and [16]. To determine exchangeable sodium and potassium, the soil had been saturated with ammonium acetate $(1 \mathrm{~N})$, as described by [18], then exchangeable sodium and potassium determined by Flame Photometer Device, model - CORNING - 400. The $\left(\mathrm{SiO}_{2}\right)$ was Table (1): Total element analysis and leaching factor for the studied pedons in Kalar area. determined directly from the soil powder using X - Ray Fluorescence Analyzer, model - Ridaku - Japan, as a percentage. While $\left(\mathrm{Na}_{2} \mathrm{O}, \mathrm{K}_{2} \mathrm{O}\right)$ was determined by Fusion Alkali Method described by [16] which put (1gm) of fusion powder $\left(1.5 \mathrm{gm}\right.$ of $\mathrm{Na}_{2} \mathrm{CO}_{3}+1.5 \mathrm{gm}$ of $\left.\mathrm{K}_{2} \mathrm{CO}_{3}\right)$ in the crucible and added $(1 \mathrm{gm})$ of powdered soil then covered with $(2 \mathrm{gm})$ of fusion powder after that put in the oven at $\left(400 \mathrm{C}^{\circ}\right)$ for $(40$ minutes), then put in the oven at $\left(800 \mathrm{C}^{\circ}\right)$, and filtrated with hot distillated water, completed to $(200 \mathrm{ml})$ with distillated water, diluted (100 time) by distillated water and reading the amount of (K and Na) by Flame Photometer Device, model CORNING -400 . After preparing the standard solution, finally converted to $\left(\mathrm{Na}_{2} \mathrm{O}\right.$ and $\left.\mathrm{K}_{2} \mathrm{O}\right)$ using of molecular weight. The value of leaching factor was obtained by using the below equation by [19].

$$
\begin{aligned}
& \text { LeachingFactor } \\
& =\frac{\left(\mathrm{Na}_{2} \mathrm{O}+\mathrm{K}_{2} \mathrm{O}\right) / \mathrm{SiO}_{2} \text { ofweatheringhorizon }}{\left(\mathrm{Na}_{2} \mathrm{O}+\mathrm{K}_{2} \mathrm{O}\right) / \mathrm{SiO}_{2} \text { ofparentmaterial }}
\end{aligned}
$$

Soils were classified to the family level using (Keys to Soil Taxonomy) indicated by [9].

\section{Results and Discussions}

The studied pedons exhibited differences in their degree of developments depending as reflected by the differences of the horizons nature wherefrom theirs type, thickness and sequential which are reflected on the nature of surface diagnostic horizon (epipedon) and subsurface horizon (endopedon) [20]. It is obvious from the table (1) that the studied soils appear differences whether in the leaching factor of the same pedon or among the pedons. These differences going with some physical properties of the pedons which represented by soil particles distribution and bulk density ( Table 2). The results refer to the low value of leaching factor for surface horizons compared with subsurface horizon (B) except pedon (2) because of high accumulation of clay in surface horizon $(212.8 \mathrm{gm} / \mathrm{kgm})$ than other pedons when compared with the amount of sand. In addition to the high accumulation of silt in surface horizon of this pedon (539.7 $\mathrm{gm} / \mathrm{kgm}$ ), as the lowest location of this pedon caused the fine particles to be accumulated and as a result decrease each of the movement of these particles and the leaching of the high content of calcium carbonate in (Ap) than in $\left(\mathrm{Bt}_{1}\right)$ as a reverse with other pedons and as a result to prevent the movement of soil particles ,table (3); so the leaching factor was high in pedon (2) compared with other pedons. 
Kurdistan Journal of Applied Research (KJAR) | Print-ISSN: 2411-7684 - Electronic-ISSN: 2411-7706 | kjar.spu.edu.iq Volume $1 \mid$ Issue $2 \mid$ December 2016 | DOI: 10.24017/science.2016.1.2.1

\begin{tabular}{|c|c|c|c|c|c|c|}
\hline Pedons & Horizon & Depth (cm) & $\mathrm{Na}_{2} \mathrm{O} \%$ & $\mathbf{K}_{2} \mathrm{O} \%$ & $\mathrm{SiO}_{2} \%$ & Leaching factor \\
\hline \multirow{4}{*}{1} & Ap & $0-25$ & 0.80 & 0.34 & 40.68 & 1.05 \\
\hline & $\mathrm{B}_{1}$ & $25-85$ & 0.74 & 0.89 & 40.33 & 1.52 \\
\hline & $\mathrm{Bk}_{2}$ & $85-115$ & 0.90 & 0.61 & 39.75 & 1.43 \\
\hline & $\mathrm{C}$ & $115-185$ & 0.99 & 0.13 & 42.12 & 1.00 \\
\hline \multirow{3}{*}{2} & Ap & $0-25$ & 1.23 & 0.64 & 40.24 & 1.64 \\
\hline & $\mathrm{Bt}_{2}$ & $80-130$ & 1.23 & 0.61 & 40.10 & 1.62 \\
\hline & $\mathrm{C}$ & $130-175$ & 0.68 & 0.44 & 39.46 & 1.00 \\
\hline \multirow{3}{*}{3} & Ap & $0-25$ & 0.90 & 0.51 & 41.48 & 0.89 \\
\hline & $\mathrm{Btk}_{1}$ & $25-100$ & 0.93 & 0.64 & 39.24 & 1.05 \\
\hline & $\mathrm{Btk}_{2}$ & $100-135$ & 1.35 & 0.36 & 40.99 & 1.10 \\
\hline 4 & $\mathrm{C}$ & $85-145$ & 1.20 & 0.61 & 44.27 & 1.00 \\
\hline \multirow{4}{*}{5} & Ap & $0-30$ & 1.02 & 0.51 & 40.37 & 0.89 \\
\hline & Btk & $30-100$ & 0.74 & 0.79 & 40.08 & 0.90 \\
\hline & $\mathrm{C}_{1}$ & $100-130$ & 1.29 & 0.29 & 38.65 & 0.96 \\
\hline & $\mathrm{C}_{2}$ & $130-170$ & 0.80 & 0.91 & 38.66 & 1.04 \\
\hline \multicolumn{3}{|c|}{ Average of $\mathrm{C}$} & 1.05 & 0.60 & 38.66 & \\
\hline
\end{tabular}

Table (2): Some physical properties for the studied pedons in Kalar area.

\begin{tabular}{|c|c|c|c|c|c|c|c|c|}
\hline \multirow{2}{*}{ Pedons } & \multirow{2}{*}{ Horizon } & \multirow{2}{*}{ Depth (cm) } & \multicolumn{3}{|c|}{ Total Content (g/kg) } & \multicolumn{2}{|c|}{ Density (Mg/m3) } & \multirow{2}{*}{$\begin{array}{c}\text { Porosity }( \\
\%)\end{array}$} \\
\hline & & & Sand & Silt & Clay & Bulk & Particle & \\
\hline \multirow{4}{*}{1} & Ap & $0-25$ & 324.3 & 465.2 & 210.5 & 1.31 & 2.53 & 48.22 \\
\hline & $\mathrm{B} 1$ & $25-85$ & 310.4 & 453.2 & 236.4 & 1.36 & 2.66 & 48.87 \\
\hline & $\mathrm{Bk} 2$ & $85-115$ & 326.0 & 439.9 & 234.1 & 1.42 & 2.63 & 46.01 \\
\hline & $\mathrm{C}$ & $115-185$ & 770.8 & 124.5 & 104.7 & 1.45 & 2.56 & 43.36 \\
\hline \multirow{4}{*}{2} & Ap & $0-25$ & 247.5 & 539.7 & 212.8 & 1.40 & 2.54 & 44.88 \\
\hline & Bt1 & $25-80$ & 144.4 & 478.0 & 377.6 & 1.43 & 2.61 & 45.21 \\
\hline & Bt2 & $80-130$ & 173.7 & 495.4 & 330.9 & 1.52 & 2.55 & 40.39 \\
\hline & $\mathrm{C}$ & $130-175$ & 260.3 & 421.2 & 318.5 & 1.54 & 2.68 & 42.54 \\
\hline \multirow{4}{*}{3} & Ap & $0-25$ & 298.4 & 479.3 & 222.3 & 1.36 & 2.53 & 46.25 \\
\hline & Btk1 & $25-100$ & 174.2 & 502.0 & 323.8 & 1.44 & 2.54 & 43.31 \\
\hline & Btk2 & $100-135$ & 288.0 & 435.4 & 276.6 & 1.47 & 2.56 & 42.58 \\
\hline & $\mathrm{C}$ & 135-155 & 470.1 & 334.1 & 195.8 & 1.51 & 2.65 & 43.02 \\
\hline \multirow{3}{*}{4} & Ap & $0-25$ & 336.8 & 452.9 & 210.3 & 1.33 & 2.63 & 49.43 \\
\hline & $\mathrm{Bt}$ & $25-85$ & 420.5 & 327.4 & 252.1 & 1.43 & 2.52 & 43.25 \\
\hline & $\mathrm{C}$ & $85-145$ & 768.1 & 98.0 & 133.9 & 1.41 & 2.61 & 45.98 \\
\hline \multirow{4}{*}{5} & Ap & $0-30$ & 288.4 & 503.7 & 207.9 & 1.42 & 2.47 & 42.51 \\
\hline & Btk & $30-100$ & 258.1 & 465.8 & 276.1 & 1.45 & 2.57 & 43.58 \\
\hline & $\mathrm{C} 1$ & $100-130$ & 327.2 & 449.6 & 223.2 & 1.48 & 2.81 & 47.33 \\
\hline & $\mathrm{C} 2$ & $130-170$ & 366.9 & 405.0 & 228.1 & 1.51 & 2.72 & 44.49 \\
\hline
\end{tabular}

Table (3): Some chemical properties for the studied pedons in Kalar area 
Kurdistan Journal of Applied Research (KJAR) | Print-ISSN: 2411-7684 - Electronic-ISSN: 2411-7706 | kjar.spu.edu.iq Volume $1 \mid$ Issue $2 \mid$ December 2016 $\mid$ DOI: 10.24017/science.2016.1.2.1

\begin{tabular}{|c|c|c|c|c|c|c|}
\hline \multirow[t]{2}{*}{ Pedons } & \multirow[t]{2}{*}{ Horizon } & \multirow[t]{2}{*}{ Depth (cm) } & \multirow{2}{*}{$\begin{array}{l}\text { Total Lime } \\
\quad(\mathrm{g} / \mathrm{kg})\end{array}$} & \multirow{2}{*}{$\begin{array}{c}\text { Organic Matter } \\
(\mathrm{g} / \mathrm{kg})\end{array}$} & \multicolumn{2}{|c|}{$\begin{array}{c}\text { Exchangeable Cations (cmolc/kg } \\
\text { soil) }\end{array}$} \\
\hline & & & & & $\mathrm{Na}+$ & $\mathbf{K}+$ \\
\hline \multirow{4}{*}{1} & Ap & $0-25$ & 254 & 15.0 & 1.20 & 0.17 \\
\hline & $\mathrm{B} 1$ & $25-85$ & 295 & 8.0 & 1.14 & 0.09 \\
\hline & $\mathrm{Bk} 2$ & $85-115$ & 295 & 5.1 & 1.01 & 0.08 \\
\hline & $\mathrm{C}$ & $115-185$ & 240 & 2.0 & 0.70 & 0.04 \\
\hline \multirow{4}{*}{2} & Ap & $0-25$ & 295 & 12.9 & 1.14 & 0.19 \\
\hline & Bt1 & $25-80$ & 285 & 10.0 & 1.01 & 0.09 \\
\hline & $\mathrm{Bt} 2$ & $80-130$ & 280 & 7.0 & 0.89 & 0.06 \\
\hline & $\mathrm{C}$ & $130-175$ & 280 & 1.0 & 0.95 & 0.09 \\
\hline \multirow{4}{*}{3} & Ap & $0-25$ & 235 & 13.7 & 1.15 & 0.09 \\
\hline & Btk1 & $25-100$ & 310 & 9.0 & 1.03 & 0.05 \\
\hline & Btk2 & $100-135$ & 300 & 1.0 & 0.89 & 0.07 \\
\hline & $\mathrm{C}$ & $135-155$ & 250 & 0.5 & 0.95 & 0.04 \\
\hline \multirow{3}{*}{4} & Ap & $0-25$ & 265 & 13.6 & 1.33 & 0.23 \\
\hline & $\mathrm{Bt}$ & $25-85$ & 175 & 8.3 & 1.01 & 0.11 \\
\hline & $\mathrm{C}$ & $85-145$ & 170 & 1.5 & 0.76 & 0.10 \\
\hline \multirow{4}{*}{5} & Ap & $0-30$ & 300 & 13.0 & 1.26 & 0.21 \\
\hline & Btk & $30-100$ & 310 & 5.4 & 1.14 & 0.09 \\
\hline & $\mathrm{C} 1$ & $100-130$ & 240 & 0.7 & 1.33 & 0.08 \\
\hline & $\mathrm{C} 2$ & $130-170$ & 280 & 0.5 & 1.26 & 0.08 \\
\hline
\end{tabular}

These results show the partial improvement of the hydrous properties for the surface horizons of all pedons except pedon (2) represented by increasing porosity, low content of clay, and high content of silt and sand in addition to the improvement of soil structure in these horizons especially granular type as a result of biological activity which partially increases the content of organic matter, these all factors belonged to low value of leaching factor for surface horizons, which ranges from (0.87) in (Ap) horizon of pedon (4) to (1.64) in (Ap) horizon of pedon (2).

Moreover, the results indicate an increase in the leaching factor value in subsurface horizon (B) due to the effect of high content of fine materials assists in increasing the bulk density, which affected negatively to the movement of soil contents. Therefore the leaching factor value was about (0.90) in (Btk) in pedon (5) with clay content $(276.1 \mathrm{gm} / \mathrm{kgm})$, and (1.62) in $\left(\mathrm{Bt}_{2}\right)$ of pedon (2) with clay content $(330.9 \mathrm{gm} / \mathrm{kg})$. These results do not refer to the present dry condition, but it refer to paleoclimatic condition [21].

Generally, pedon (4) and (5) have the lowest values of leaching factor compared with other pedons. The differences in leaching factor value for individual pedon or among the studied pedons mainly reflect the differences in the activity of weathering processes which releases the easy releasable elements especially sodium and potassium (Table 3), in addition to the difference in activity of leaching processes which partially removes the released elements from weathering processes.

However increasing weathering and leaching activity processes decrease the leaching factor value as a result of partial increasing of difficult release and movement elements especially silicate. Therefore, surface horizons generally show the lowest leaching factor value which accepted with increasing activity of weathering and leaching in these horizons because they are in contact with external environmental factors especially climate, vegetation and land use nature. While the partial increase of leaching factor value in subsurface horizons was due to the translocation and accumulation of easy releasing and movement elements from surface horizon to these horizons compared with weak effect of difficult releasing and elements movement represent by silicate.

The differences in leaching factor value among the studied pedon may be due to the effect of land use pattern and local conditions of each pedon which have great effect on the intensity of weathering and leaching processes among pedons. As well as the differences in some soil properties especially texture and structure, have a great role in limitation of leaching factor value.

Table (4): Classification of the studied pedons in Kalar area.

\begin{tabular}{|c|c|}
\hline Pedon & Soil Family \\
\hline $\mathbf{1}$ & Loamy, mixed, hyperthermic, superactive, calcareouseTypicHaplocambids \\
\hline
\end{tabular}


Kurdistan Journal of Applied Research (KJAR) | Print-ISSN: 2411-7684 - Electronic-ISSN: 2411-7706 | kjar.spu.edu.iq Volume $1 \mid$ Issue 2 | December 2016 | DOI: 10.24017/science.2016.1.2.1

\begin{tabular}{|c|c|}
\hline $\mathbf{2}$ & Fine loamy, mixed, hyperthermic, superactive, calcareouseTypicHaploargids \\
\hline $\mathbf{3}$ & Fine loamy, mixed, hyperthermic, superactive, calcareouseTypiccalciargids \\
\hline $\mathbf{4}$ & Loamy, mixed, hyperthermic, superactive, calcareouseTypicHaploargids \\
\hline $\mathbf{5}$ & Fine loamy, mixed, hyperthermic, superactive, calcareouseTypiccalciargids \\
\hline
\end{tabular}

All the studied soils were classified to Aridisols order depending on (Keys to Soil Taxonomy) by [9]. The entity of Argilic and Cambic subsurface horizons (endopedons) and presents of calcareouse through the pedogenic processes which are eluviations, illuviation, calcification and decalcification at the studied soils ,table (4); which indicate the occurrence of translocation of clay materials from surface horizon and hence accumulating in subsurface horizon does not reflect the effect of immediate dry climatic conditions nature which Aridisols is existed, were the soil temperature regime of studied area is hyperthermic [22], while such horizons which were formed under paleoclimatic conditions assisted during the ancient centuries in formation of these horizons or the accumulation of clay in these horizons may be due to in situ formation.

This type of clay distribution could be due to the paleoeffect of pedogenic processes responsible for the formation of these soils [21].

It may invariably be the pedogenic processes including calcification, decalcification, eluviation and illuviation which are responsible for formation and development of the soil in dry areas is similar to those in wet areas, but the average of soil formation in dry areas is low due to the low water content, thus because of low water content in such areas, parent materials are mostly affected rather than other soil formation components, where the effect of water on leaching the soluble salts and translocation of colloidal materials from surface horizons to subsurface horizon are very limited

\section{Conclusions}

The results indicate the presence of some differences in values of leaching factor with the same pedon and among the studied pedons. In general, the value of the leaching factor increase with depth in B horizon then decrease in the lower part of the all pedons. This may reflects the down movement of fine soil particles particularly clay. The clay movement cannot be related to the dominant dry climatic condition, but may related to more wet paleoclimatic conditions, and this movement eventually occurred because of local conditions.

\section{REFERENCES}

[1] S. N. Azeez. Identification of soil map units and vegetation indices using geoinformatics techniques for Garmyan, Kurdistan Region, Iraq, Ph.D. dissertation. University of Sulaimani, Kurdistan Region, Iraq, 2013.

[2] P. Buringh. Soil and soil condition in Iraq, Ministry of Agriculture. Baghdad, Iraq, 1960.
[3] S. M. Ahmad. Natural map of Iraqi Kurdistan region, Accepted by the Ministry of Higher Education and Scientific Research/ Kurdistan region copywriters $7 / 16 / 2917$ on 22 th June 2005.

[4] F. H. Al-Taie. The soils of Iraq, Ph.D. dissertation. State University of Ghant, Belgium, 1968.

[5] A. S. Muhaimeed; A. J. Saloom; K. A. Saleim and K. A. Alaane. Classification and Distribution of Iraqi Soils, IJAIR. Vol. 2, No. 6, PP. 997-1002. 2014.

[6] H.V. Dunnington. Generation, migration, accumulation and dissipation of oil in northern of Iraq, In. L.G. Weeks (ed.). Habitat of Oil, Amer. Assoc. Petroleum Geologist. PP. 1194-1251. 1958.

[7] N. S. Kharrufa. Simplified equation for evaportranspiration in arid regions, BeitrageZure Hydrology, No. 5. PP. 39-47. 1985.

[8] FAO (Food and Agriculture Organization) of U.N. Agricultural pest and their control principles, Offset press, Erbil-Iraq, 2000.

[9] Soil Survey Staff. Keys to soil taxonomy, Hand book. 10th ed. Natural Resources conservation service. Washington D.C. 2006.

[10] Soil Survey Staff. National soil survey handbook. Title, 430, Vol. Washington, D.C. USDA Natural Resources conservation service. 1993.

[11] V.J. Kilmer and L.T. Alexander. Methods of making mechanical analysis of soils, Soil Science Journal, Vol. 68, PP. 15-24, 1949.

[12] M. L. Jackson. Soil chemical analysis, Advanced course, University Department of Wisconsin, Collage of agriculture Madison, 1956.

[13] M. L. Jackson. Soil chemical advanced course. 2nd ed. publ. by the author, Madison, W.I. U.S.A. 1979.

[14] C. A. Black. Methods of soil analysis, Am. Soc. of Agronomy, No. 9, Part 1 and 2. 1965.

[15] J. A. Vomocil. Porosity. In: C. A. Black (ed.). Methods of soil analysis,. Am. Soc. of Agronomy, Madison Wisconsin, No.9: Part 1, PP. 315-318, 1965.

[16] P. R. Hesse. A text book of soil chemical analysis, Chemical publ. Co. Inc. New York, U.S.A. 1972.

[17] C. S. Piper. Soil and Plant Analysis, Interscience Publishers, Inc., New York, 1950.

[18] W.P. Kelley. Cation exchange in soil, Reinhold publishing crop. New York, U.S.A. 1948.

[19] P. W. Birkeland. Pedology, weathering, and geomorphological research, New York, Oxford. University press, London, England. 1974.

[20] S. N. Aziz. Survey and classification of some soils from Kurdistan region, M. Sc. Thesis. College of 
Kurdistan Journal of Applied Research (KJAR) | Print-ISSN: 2411-7684 - Electronic-ISSN: 2411-7706 | kjar.spu.edu.iq Volume 1 | Issue 2 | December 2016 | DOI: 10.24017/science.2016.1.2.1

Agriculture. Sulaimani University, Kurdistan Region, Iraq, 2006.

[21] S. N. Aziz.; A. S. muhaimeed and I. M. Amin, Climatic conditions effects on formation and development status of some soils in northern part of Iraq/Kurdistan region, Journal of Kirkuk University, Scientific Studies, Vol. 4, No.1, 2009.

[22] J. K. Kassim; K. Z. Al-Janabi and M. I. Karim. Soil temperature regimes in Iraq: II-Relationships between soil temperature and latitude, longitude and elevation, Journal of Agriculture and Water resources Research Vol. 8, No. 1, PP. 111-121, 1989. 